\title{
Pathogens with potential impact on reproduction in captive and free-ranging European bison (Bison bonasus) in Poland - a serological survey
}

\author{
Anna Didkowska ${ }^{1 *}$, Daniel Klich², Anna Hapanowicz ${ }^{1}$, Blanka Orłowska ${ }^{1}$, Marta Gałązka ${ }^{1}$,
} Magdalena Rzewuska ${ }^{3}$, Wanda Olech ${ }^{2}$ and Krzysztof Anusz ${ }^{1}$

\begin{abstract}
Background: The European bison is an endangered species, and as such it is extremely important to monitor herds for pathogens which can lead to reproductive failure. The aim of the present study was to determine the current prevalence of antibodies to pathogens known to potentially influence reproduction in European bison. Serum samples from 183 bison, originating from different parts of Poland, were tested using commercial ELISA tests for antibodies to Chlamydia spp., Coxiella burnetti, Leptospira interrogans, Neospora caninum and Toxoplasma gondii; the findings were compared between captive and main free-ranging herds, and with regard to the influence of demographic factors such as age and sex. The prevalence of seropositivity was also checked with regard to location and the animal species sharing it.

Results: Chlamydia spp. antibodies were present in 48 out of 130 (36.9\%) tested samples. Coxiella burnetii was found in one sample out of 178 (0.58\%). N. caninum in 36 out of 172 (20.9\%) and T. gondii in 23 out of 172 (13.4\%). No sample was positive for leptospirosis. Neither sex nor age appeared to have a significant effect on the occurrence of antibodies to the identified species. The prevalence of Chlamydia spp. in the samples varied significantly according to location; however, similar frequency ranges were observed between free ranging and captive herds. In contrast, antibodies to N. caninum were more common in free-ranging herds than captive herds, with the highest frequency observed in the Bieszczady Mountains.
\end{abstract}

Conclusions: Chlamydia spp., N. caninum and T. gondii might have a similar impact on the reproductive potential of European bison as they have on cattle. The high occurrence of antibodies to N. caninum in bison from the Bieszczady Mountains may be associated with the relatively high density of the wolf population in the area.

Keywords: Chlamydia spp., Coxiella burnetii, ELISA, European bison, Leptospira interrogans, Neospora caninum, reproductive system, serology, Toxoplasma gondii, zoonosis

*Correspondence: anna_didkowska@sggw.edu.pl

${ }^{1}$ Department of Food Hygiene and Public Health Protection, Institute of Veterinary Medicine, Warsaw University of Life Sciences (SGGW), Nowoursynowska 166, 02-787 Warsaw, Poland

Full list of author information is available at the end of the article

\section{Background}

The European bison (Bison bonasus) is a strictlyprotected species which requires active conservation measures [1]. Following many years of hunting, leading nearly to its extinction, its population in Poland has been rebuilt since 1919 [2], and the country is currently 
home to 2269 individuals: 2048 in free-ranging herds and 221 in captive breeding [3]. However, its recovery continues $[4,5]$, and there is a growing need for effective health monitoring [1]. This is extremely important in European bison due to the relatively limited gene pool [6] and high susceptibility to infectious diseases [7], particularly considering the environmental threats it faces (see: $[8,9]$ ).

Bovine tuberculosis (BTB) has had a considerable impact on the Polish bison population in recent years [10], and as such, the population is regularly monitored for BTB [11]. However, a number of other diseases also have zoonotic potential and should also be monitored. For example, chlamydiosis (chlamydophilosis), leptospirosis, Q fever and toxoplasmosis, all with zoonotic potential, have been identified in bison worldwide, and may pose a similar risk for reproduction as they do for cattle [12-14]. In addition, there is a need to monitor a number of other diseases that can have an adverse effect on the population size, such as brucellosis, by increasing the risk of abortions, stillbirths or weak calves [15], as well as those also that can impair male fertility, such as multi-etiological balanoposthitis, caused by Corynebacterium spp., Pseudomonas aeruginosa, Escherichia coli, Fusobacterium necrophorum, Arcanobacterium pyogenes, Staphylococcus spp. (coagulase negative), Streptococcus spp., Onchocerca spp., and Trueperella pyogenes [16, 17].

Chlamydial infections have been detected in over 450 species, including birds, mammals and humans [18]. It has recently been recommended that, due to high similarity of their genomes, the genera Chlamydia and Chlamydophila, within the family Chlamydiaceae, should be merged into a single genus Chlamydia [19]. In cattle, although chlamydial infection results in a variety of systemic symptoms, most concern the reproductive system [20]: chlamydiosis may lead to late abortion, as well as endometritis, vaginitis, seminal vesiculitis and weak calf births [21]. Infection by Chlamydia abortus, Chlamydia suis and Chlamydia psittaci, can lead to reproductive disorders, and all have been detected in Polish cattle herds [22].

Another disease which can lead to problems with reproduction is leptospirosis, caused by the bacterium Leptospira. The bacterium survives best in warm and wet conditions, and recent years have seen the disease extend its range, probably as a result of climate change and increasing globalization [23, 24]. Antibodies to Leptospira Bataviae, Bratislava, Canicola, Hardjo, Hebdomadis, Pomona, Cynopteri and Grippotyphosa have been detected in cattle in Poland [25]. Like Chlamydia, Leptospira can also have a negative impact on reproduction in cattle, causing abortions, embryonic deaths or infertility [26].
The most common symptoms of Coxiella burnetii infection in ruminants are abortion and stillbirth [27], and its main reservoirs are domestic ruminants, which spread the bacteria through urine, feces, milk, aminiotic fluid and placental tissue [28]. Ticks also play an important role in infection: twelve species are known to act as C. burnetii vectors [29], all of which have been found in Poland [30]. Three of them, Ixodes persulcatus, Ixodes ricinus and Dermacentor reticulatus, have been confirmed as ectoparasites in European bison [31]. Antibodies to C. burnetti have been found in 109 of 167 tested free-living species [32], including bison [16].

Bison reproduction can also be impaired by two parasitic diseases: neosporosis and toxoplasmosis. Regarding the former, Neospora caninum is recognized as an important agent causing abortion in cattle [13]; in addition, if the calf is born alive, there is a high probability of pelvic hyperextension and hydrocephalus, as well as neurological symptoms such as widespread ataxia [33]. The definitive hosts of $N$. caninum are dogs and some wild canids, which shed oocysts after eating the tissues of infected animals [34]. Toxoplasmosis, caused by Toxoplasma gondii, also has a potentially harmful effect on European bison reproduction. T. gondii oocysts are shed in the environment by the felid definitive hosts. Infected intermediate hosts may show neurological symptoms (canidae, pigs, poultry) or problems with the reproductive system (ruminants, pigs) [35].

Due to their close genetic relationship with cattle and the fact that they often share pastures, bison require monitoring for diseases that can be transmitted between the two species. Importantly, some of those etiological agents have zoonotic potential, and hence can represent public health threats through contact with infected animals or the consumption of food products of animal origin. Free-ranging populations of bison are managed in different ways, and are thus exposed to different health risks $[8,9]$. They also occupy individual enclosures with different habitat conditions, resulting in the level of disease intensity varying between locations [11]. The occurrence of disease may be governed by environmental factors or by herd management protocols. The most convenient and common method for monitoring the occurrence of pathogens in wildlife is serological sampling [15, 16]. Samples can be relatively easy collected both ante mortem during routine immobilization (e.g. when putting on telemetry collars) and post mortem following natural death or culling.

The aim of the present study was to determine the prevalence of selected diseases known to potentially influence reproduction in the Polish bison population, viz. chlamydiosis, leptospirosis, Q fever, neosporosis and toxoplasmosis, with the use of a complex serological 
survey. The study also compares the seroprevalence of antibodies to Chlamydia spp., $N$. caninum and T. gondii among individuals kept in captivity with those from key free-ranging herds in Poland.

\section{Results}

Chlamydia spp. antibodies were detected in 48 of 130 samples (36.9\%). C. burnetii was detected in one out of 178 (0.58\%), N. caninum in 35 out of 172 (20.3\%), and T. gondii in 23 out of 172 (13.4\%). None of the 170 samples tested for the L. interogans serovar Hardjo antibodies was positive (Table 1).

Neither sex or age had any significant influence on the occurrence of antibodies to Chlamydia spp., $N$. caninum or $T$. gondii in European bison. All candidate models presented higher AIC values than the null model with T. gondii. However, location significantly differentiated the occurrence of antibodies in European bison in both of the other models, i.e. those based on Chlamydia spp. $(\mathrm{p}=0.001)$ and $N$. caninum $(\mathrm{p}=0.022)$ (Table 2$)$.

The frequency of Chlamydia spp. infection varied considerably with regard to location, for both the freeranging (0.17 to 0.64$)$ and captive herds (0.08 to 0.45 ) (Fig. 1, Table S1). The lowest levels were observed in the free-ranging European bison from the Białowieska Forest (BIA) and the captive herds in Białowieża (BIA $\mathrm{C}_{c}$; however only captive herds in Białowieża $\left(B_{c} A_{c}\right.$ ) and other captive herds $\left(\mathrm{OT}_{\mathrm{c}}\right)$ differed significantly from those observed in the free-ranging herds in the Borecka Forest (BOR) and Knyszyńska Forest (KNY).

Among the captive herds, the highest probability of infection with Chlamydia spp. was observed for Pszczyna $\left(\mathrm{PS}_{\mathrm{c}}\right)$.

The sero-prevalence of $N$. caninum infection differed significantly between individual locations; however, this frequency differed significantly between free-ranging herds $(0.17$ to 0.88$)$ and captive ones (0.00 to 0.21$)$ (Fig. 2, Table S2). The free-ranging European bison in the Bieszczady (BIE) herd were significantly more likely to be
Table 2 Effect of location on the occurrence of antibodies to Chlamydia spp. and N. caninum in European bison

\begin{tabular}{lllll}
\hline Pathogen & Source & $\mathbf{X}^{\mathbf{2}}$ & Df & $\boldsymbol{P}$ \\
\hline Chlamydia spp. & Intercept & 9.43 & 1 & $0.002^{*}$ \\
& Location & 23.81 & 7 & $0.002^{*}$ \\
N. caninum & Intercept & 0.00 & 1 & 0.999 \\
& Location & 16.33 & 7 & $0.022^{*}$ \\
\hline
\end{tabular}

Legend: Effect of location on the occurrence of antibodies to Chlamydia spp. (model: $x^{2}=31.85, \mathrm{df}=7, p<0.001, N=130$ ) and $N$. caninum (model: $\mathrm{X}^{2}=33.15$, $\mathrm{df}=7, p<0.001, N=172$ ) in European bison. Sex did not have a significant influence on the occurrence of Chlamydia spp., nor did age on N. caninum therefore, these were excluded from the models in the backward elimination procedure (*statistically significant predictors)

infected with $N$. caninum than the others, i.e. there was a significantly higher frequency of the pathogen in the population. The free-ranging herds in Knyszynska Forest (KNY) were significantly more likely to be infected than one out of the four breeding centers, viz. those of the Pszczyna $\left(\mathrm{PS}_{\mathrm{c}}\right)$.

\section{Discussion}

Significant numbers of European bison were found to be positive for chlamydiosis (36.9\%), neosporosis (20.9\%) or toxoplasmosis (13.4\%). Based on the known similarities between cattle and bison, these findings suggest that the European bison in these areas may be at risk of lower reproductive potential: pathogens tested in the present study are widespread, and commonly affect the reproductive system in domestic cattle $[18,26,28]$. Such data is essential for managing and protecting the European bison population, and serological monitoring can be an effective tool for further, deeper studies on this species. It should be emphasized that our findings present a fairly complete picture of the situation in the Polish European bison population, as they include individuals from four out of six free-ranging subpopulations and from 13 out of 24 captive herds.

Table 1 Seroprevalence of analyzed pathogens in European bison in free ranging and captive conditions; free-ranging: BIA

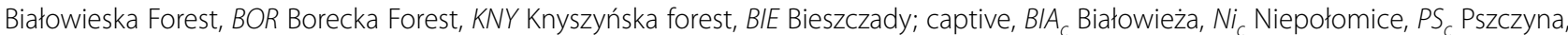
OT $T_{c}$ Other captive herds

\begin{tabular}{|c|c|c|c|c|c|c|c|c|}
\hline & \multicolumn{4}{|c|}{ Free ranging } & \multicolumn{4}{|c|}{ Captive } \\
\hline & BIA & BOR & KNY & $\mathrm{BIE}$ & $\mathrm{BIA}_{\mathrm{C}}$ & $\mathrm{NI}_{\mathrm{C}}$ & $\mathrm{PS}_{\mathrm{C}}$ & $\mathrm{OT}_{\mathrm{c}}$ \\
\hline Chlamydia spp. & $10.0 \%$ & $51.7 \%$ & $53.3 \%$ & $20.0 \%$ & $6.3 \%$ & $21.4 \%$ & $26.3 \%$ & $8.8 \%$ \\
\hline Coxiella burnetii & $10.0 \%$ & $0.0 \%$ & $0.0 \%$ & $0.0 \%$ & $0.0 \%$ & $0.0 \%$ & $0.0 \%$ & $0.0 \%$ \\
\hline Neospora caninum & $30.0 \%$ & $17.2 \%$ & $33.3 \%$ & $46.7 \%$ & $9.4 \%$ & $21.4 \%$ & $0.0 \%$ & $11.8 \%$ \\
\hline Toxoplasma gondii & $10.0 \%$ & $20.7 \%$ & $6.7 \%$ & $13.3 \%$ & $12.5 \%$ & $0.0 \%$ & $10.5 \%$ & $17.6 \%$ \\
\hline Leptospira Hardjo & $0.0 \%$ & $0.0 \%$ & $0.0 \%$ & $0.0 \%$ & $0.0 \%$ & $0.0 \%$ & $0.0 \%$ & $0.0 \%$ \\
\hline
\end{tabular}




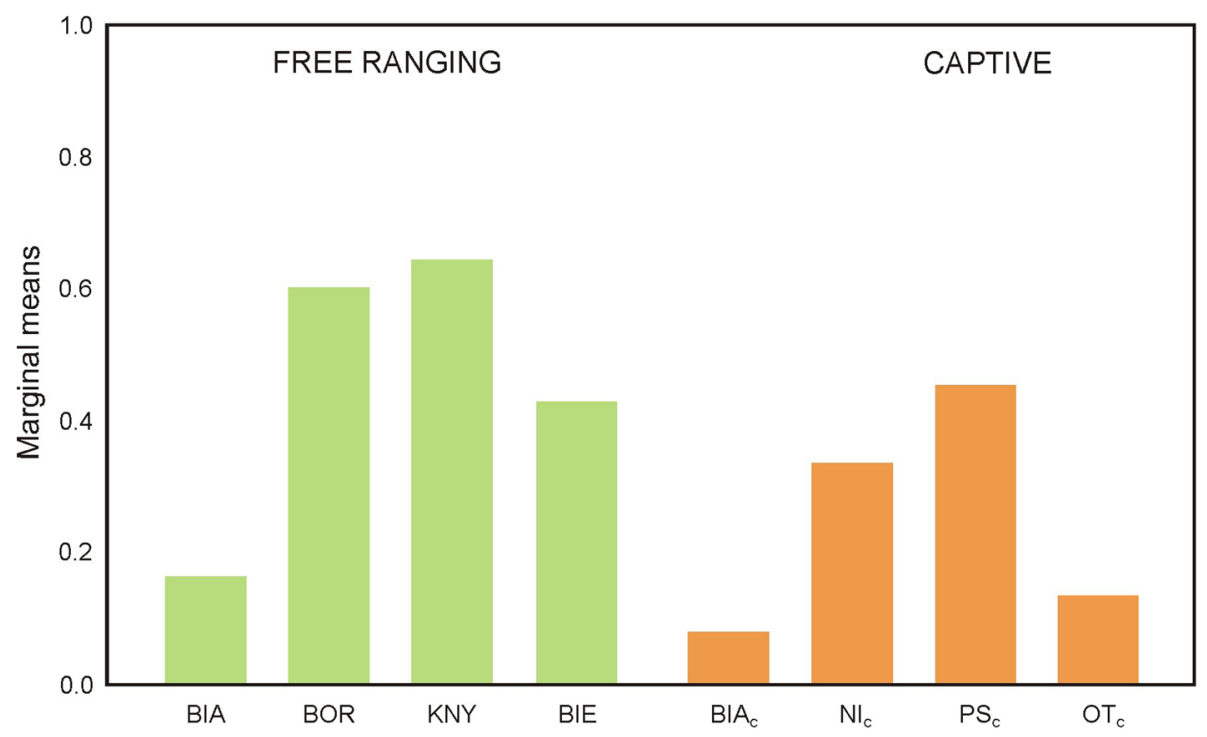

Fig. 1 Frequency of infection by Chlamydia spp. in European bison from selected locations. Legend: Significant differences presented in Table S1. Free-ranging herds: BIA-Białowieska forest, BOR-Borecka forest, KNY-Kyszyńska forest, BIE-Bieszczady. Captive herds: BIA - Białowieża, $\mathrm{Ni}_{c}$-Niepołomice, PS $_{c}$ - Pszczyna, OT ${ }_{c}^{-}$Other captive herds

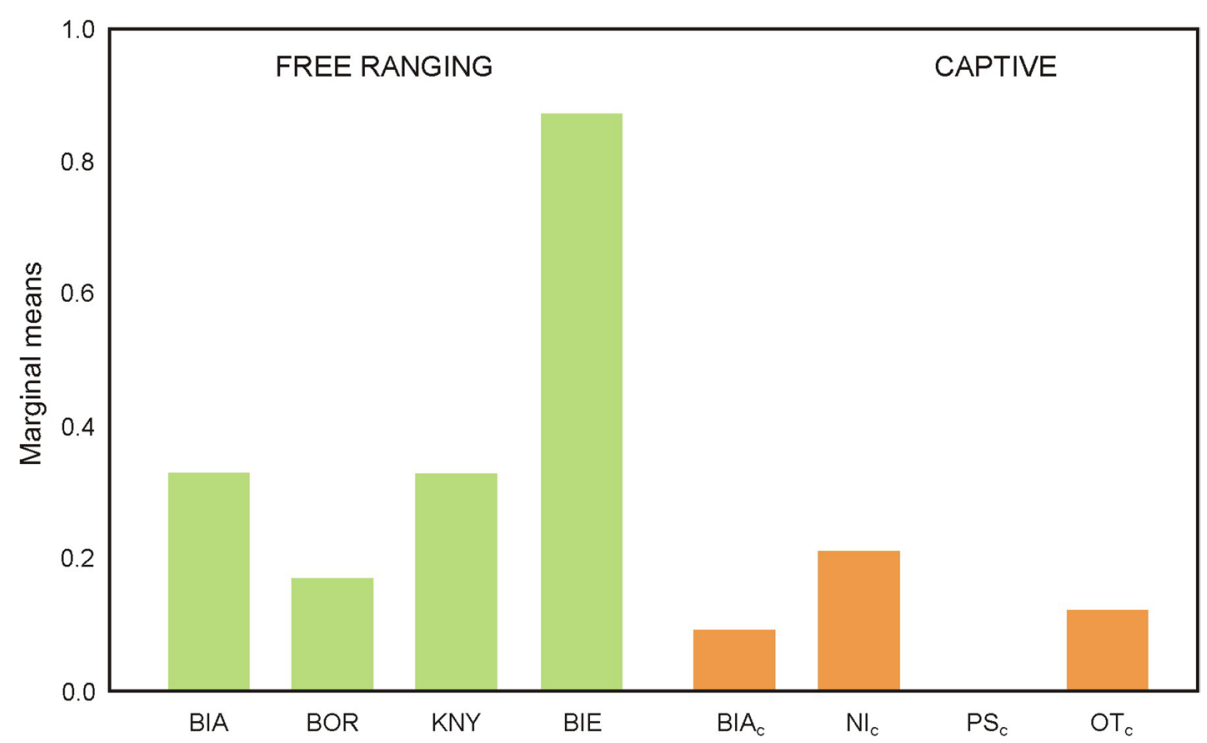

Fig. 2 Frequency of infection with N. caninum in selected locations. Legend: Significant differences presented in Table S2. Free-ranging

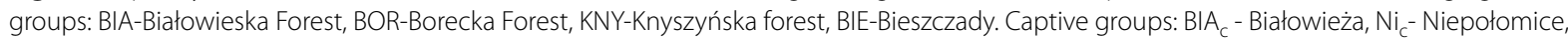
$\mathrm{PS}_{c}$ - Pszczyna, OT $_{c}$ - Other captive herds

Our findings indicate that neither sex or age had any significant effect on the occurrence of antibodies to Chlamydia spp., N. caninum or T. gondii in the studied European bison. They also confirm previous findings or N. caninum antibodies in cattle [36] or sheep [37]. However, other studies have found that both of these factors or only age was found to have a significant effect on N. caninum antibody levels in sheep or goats [38, 39].

Elsewhere, depending on the species, studies have found that neither sex or age had any significant effect on the occurrence of $T$. gondii antibodies [39], or that both factors were significant [40], or that only age played a role [37]. In addition, age and sex appear to be significant 
factors for C. abortus seropositivity in livestock [41]. Clearly, further research is needed to determine the effect of sex and age in individual studies.

In the present study, a high prevalence of antibodies against Chlamydia spp. was observed among the studied European bison (36.9\%). This is in line with results obtained in other wildlife species in Spain $(41.7 \pm 4 \%)$ [42]. This high seroprevalence of antibodies to Chlamydia spp. in European bison should not be highly alarming.

While a high percentage (around 45\%) of seropositive individuals has been confirmed in European bison in previous studies $[16,43]$, it remains unknown whether Chlamydia infection can influence their reproductive potential, despite the fact that it is believed to cause subclinical infections and is ubiquitous in ruminants [14]: a significantly higher seroprevalence has been noted in Polish cattle with reproductive disorders [22].

Our findings indicate that the highest probability of Chlamydia spp. antibodies was identified among freeranging European bison from the Knyszyńska Forest and Borecka Forest. Among the captive herds, the highest values were found in the Pszczyna herd. Interestingly, European bison from the Knyszyńska forest are more often noticed on arable lands than those from other freeranging herds [8]. We speculate, therefore, that the European bison visiting arable lands may also have a greater chance to come into contact with livestock, allowing the mutual transmission of bacteria [44], and numerous parasites [31] between livestock and free-living bison.

In contrast, the European bison from the Borecka Forest roam mainly in forest habitats. We speculate that health of these bison may be related to the wellbeing of those in the Pszczyna breeding center, because individuals are often transported between the two locations: the European bison in Pszczyna presented a higher probability of antibodies to Chlamydia spp. than other captive herds. However, further studies of the health status of the transported European bison are needed before it can be confirmed that such relocation facilitates the transmission of Chlamydia spp. between the herds. It is also possible that the higher probability of Chlamydia spp. may be linked with the presence of other wild ruminants inside the enclosure in Pszczyna, such as fallow deer (Dama dama), which have also demonstrated a high seroprevalance of Chlamydia in other countries [45].

None of the European bison were positive for Leptospira interrogans serovar Hardjo (L. Hardjo) antibodies. In contrast, they were detected in $58.3 \%$ of European bison tested in the period 1980-1983 [16] and L. interrogans was identified in $21.3 \%$ of European bison tested in the Białowieska Forest in the period 1991-2001 [43]. Antibodies to Leptospira spp. were also identified in 20 out of 240 serum samples (8.7\%) taken from European bison from different regions of Poland studied in 20112015 by microscopic agglutination test (MAT) [15].

A positive $\mathrm{Q}$ fever result was obtained for one of the 178 samples $(0.58 \%)$. Our results differ significantly to those from previous studies. In the period 1985-1988, extremely high seroprevalence (75.6\%) was noted among a group of 47 European bison tested in Borecka Forest [46]. However, it should be stressed that such studies were conducted over 30 years ago and only within a single location, which was found to be self-limiting for $\mathrm{Q}$ fever. Our present findings, indicating that $\mathrm{Q}$ fever is not currently a threat to the European bison population, are in line with the latest reports on this topic in European bison [47]. Similarly, low prevalence levels have been recorded in other wild ruminants: 6.8\% in European mouflon (Ovis orientalis musimon) and $2.4 \%$ in red deer (Cervus elaphus) in Spain [48] and 1.2\% in roe deer in Flanders [49].

Positive results for $N$. caninum antibodies were obtained in $20.9 \%$ of the studied European bison. This value is higher than in previous reports from Poland, which indicate levels of $7.3 \%(23 / 320)$ [50] and 13\% (3/23) [51]. The main transmission route of N. caninum is vertical in cattle, and probably also in European bison [52]; however, other transmission routes may also exist. Dogs (Canis lupus familiaris), coyotes (Canis latrans), dingoes (Canis lupus dingo) and gray wolves (Canis lupus) have been confirmed as definitive hosts [53-55]. In our studies, $N$. caninum infection was clearly more prevalent in European bison from the Bieszczady Mountains than in other subpopulations; this may be a result of the high density of the grey wolf population in this location: 9.2 individuals per $100 \mathrm{~m}^{2}$, compared to the mean value of 2.69 individuals per $100 \mathrm{~m}^{2}$ for Poland as a whole (http:// www.gios.gov.pl/images/pois/monitoring-wilka-i-rysia). Wolves have been reported to hunt European bison in this location [56] and feed on European bison carcasses [57]; however, no cases have been reported of N. caninum in studied wolves in Poland [58].

Another reason for the atypical results observed for the Bieszczady herd is the structure of land use in the area. Following the displacement of inhabitants after WW2, this area has mainly been used for pasture [59] and, especially in the Carpathian location, shepherd dogs are commonly used to protect farm animals against wolves [60]. Hence, there is a greater possibility that European bison may come into contact with domestic dogs in this area, which can increase the degree of infection with $N$. caninum. In addition, wolves are known to often kill farm dogs in this location (Klich, unpublished data).

In the present study, $13.4 \%$ of tested European bison were positive for $T$. gondii antibodies, which is similar 
to the seroprevalence among cattle in Poland (13\%) [61]. These results indicate that toxoplasmosis is a potential hazard for the European bison population. Antibodies to T. gondii were found in 24/95 (25\%) of free-ranging European bison in the Białowieska Forest in the period 20082011 [62] and 25/240 (10.4\%) of European bison from eight main breeding centers in 2011-2015 [15]. This seroprevalence may be due to environmental contamination with $T$. gondii oocysts shed by domestic and wild felids [63]. Although there is currently no evidence that T. gondii infection has any clinical consequences in European bison, it may nevertheless represent a potential threat to reproduction, particularly since transplacental transmission has been confirmed: $T$. gondii genetic material has been isolated from the brain of an aborted European bison fetus from Bialowieza National Park [64]. Studies have noted high levels of $T$. gondii seropositivity in Polish wildlife: $21.4 \%$ of red deer, $37.6 \%$ of wild boar (Sus scrofa), and $30.4 \%$ of roe deer [65].

The present study has some limitations. Firstly, the ELISA tests used for detection are not specifically intended for use in European bison samples. However, such tests are commonly used for serological monitoring in domestic cattle, which are closely related to European bison. Even so, to obtain greater sensitivity and specificity in future studies on European bison, further test optimization and cut-off adaptation is required based on larger numbers of samples. In addition, the tests examined the presence of IgG antibodies, which can only indicate contact with the pathogen; therefore, the results only indicate the distribution of the studied pathogens in European bison. Although this is still an important finding, future studies should confirm any serological findings with direct detection methods such as PCR. Nevertheless, despite these limitations, our findings can play an important role in recognizing current health threats and identifying the pathogens that commonly infect European bison in Poland; this is particularly important considering the small size of the European bison population and its endangered status.

\section{Conclusion}

Our findings indicate that existing Polish European bison herds have had contact with the etiological agents of chlamydiosis, neosporosis and toxoplasmosis while no $\mathrm{Q}$ fever was observed. Contrary to previous reports, no antibodies to $L$. Hardjo were detected. The seroprevalence of Chlamydia spp. in European bison depends on location, with the free-ranging herds in Knyszyńska Forest and Borecka Forest, and captive ones in Pszczyna being the most exposed; therefore, serological monitoring should be continued, especially in those populations. The free-ranging herds also demonstrated a greater prevalence of $N$. caninum antibodies than the enclosedbreeding herds, and the highest exposure was observed in the subpopulation from the Bieszczady Mountains; this is probably associated with the high number of definitive hosts, viz. grey wolves and dogs, in this area.

We suggest that further serological monitoring should be performed, together with more specific microbiological studies, especially in case of abortions, to confirm the significance of the studied pathogens on European bison propagation.

\section{Methods}

\section{Material collection}

Blood samples from 183 European bison were collected between September 2017 and December 2019 from 17 locations; four free-ranging and 13 captive herds (Fig. 3). Among the free-ranging herds, blood samples were collected from the following locations: Białowieska Forest $(n=10)$, Borecka Forest $(n=29)$, Knyszyńska Forest $(n=30)$ and Bieszczady Mountains $(n=15)$. Among the captive herds, the samples were collected from Białowieża $(n=32)$, Niepołomice $(n=14)$, Pszczyna $(n=19)$, and various other captive herds (Bałtów, Gołuchów, Kiermusy, Międzyzdroje, Muczne, Pszczyna Park, Smardzewice, Ustroń, Warsaw, Wolisko) $(n=34)$. The age of the tested European bison ranged from 0.25 (three months) to 25 years with a median value of four years. Samples were collected ante mortem $(n=106)$ and post mortem $(n=75)$. Due to the fact the bison is a strictly protected species, the collection of material could only take place during other activities related to the management of the population (e.g. immobilization before transport or placing a telemetric collar, death of animal). Samples were collected whenever there was such possibility (by qualified veterinarians during immobilisation or from dead animals).

As ante-mortem sampling was conducted during immobilisation as part of standard veterinary care, the procedure did not require approval according to II Local Ethical Committee For Animal Experiments in WULSSGGW in Warsaw. Immobilisation was conducted as described previously [66].

Collection and storage of serum samples from dead animals was based on the decision of Regional Director of Environmental Protection in Warsaw. According to the decision, collection of dead animals for scientific purposes does not need any permit as described previously [8]. Some animals were found dead or were culled for health reasons such as severe infectious disease or limb fracture, among others. Among the 23 female European bison for which autopsy protocols were available, only five presented lesions concerning the reproductive system (e.g. serous or purulent discharge from the vagina, 


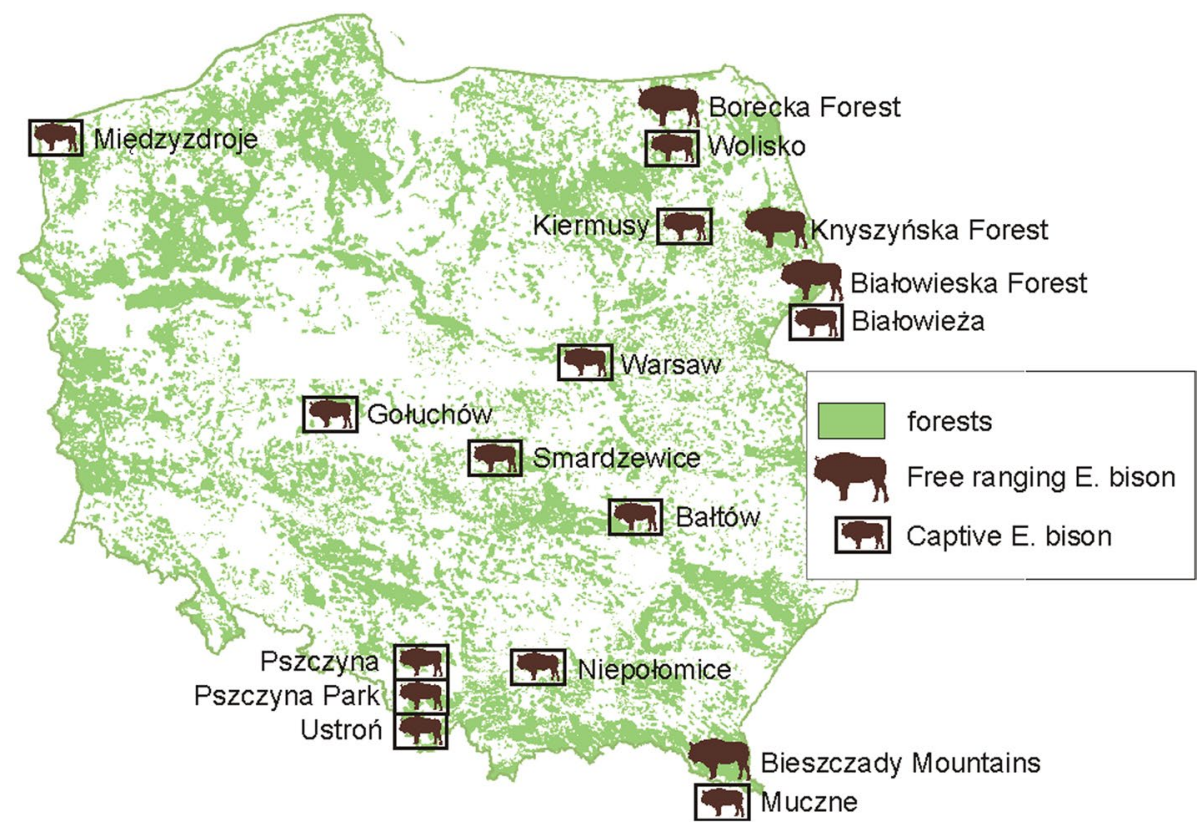

Fig. 3 Location of blood sample collection from captive and free ranging herds of European bison in Poland. The figure belongs to the authors of the publication

vaginal congestion, pyometritis); this small number did not allow for any statistical comparison of the presence of lesions and antibodies.

The blood was obtained from the jugular or tail vein during both ante-mortem and post-mortem collection, and sometimes from the heart, in the case of dead animals. The samples were collected into $10 \mathrm{ml}$ sterile tubes with clot activator; these were transported to the laboratory at $4^{\circ} \mathrm{C}$ and then centrifuged to obtain serum. Serum samples were frozen and stored at $-20^{\circ} \mathrm{C}$ for further analysis.

\section{Serological tests}

After defrosting at room temperature, the serum samples were tested with single-well indirect enzyme-linked immunosorbent assay (ELISA) kits: PrioCHECK ${ }^{\mathrm{TM}}$ Ruminant Chlamydophila spp. Ab Kit (Thermofisher, US) $(n=130)$, PrioCHECK ${ }^{\mathrm{TM}}$ Ruminant Q Fever Ab Plate Kit (Thermofisher, US) $(n=178)$, PrioCHECK ${ }^{\mathrm{TM}} L$. Hardjo Ab Plate Kit (Thermofisher, US) $(n=170)$, PrioCHECK ${ }^{\text {TM }}$ Bovine Neospora Ab 2.0 Serum/Milk Kit (Thermofisher, US) $(n=172)$, Vetline Toxoplasma ELISA KIT (Ingenasa, Spain) $(n=172)$. Different numbers of samples were used for each test as insufficient serum was collected from some of the tested European bison.

The conducted tests detect specific antibodies to Chlamydia spp., Coxiella burnetii, Leptospira interogans serovar Hardjo, Neospora caninum and Toxoplasma gondii. The first two tests are dedicated to cattle, sheep and goats, the next two are solely for cattle, and the last one is a multispecies test. All tests were conducted in accordance with the manufacturer's instructions. Results were read at a wavelength of $450 \mathrm{~nm}$ with an EPOCH spectrophotometer (BioTek Instruments Inc., US) and calculated in accordance with the manufacturer's instructions as for cattle.

Briefly, in the PrioCHECK ${ }^{\mathrm{TM}}$ Ruminant Chlamydophila spp. Ab Kit (Thermofisher, US) samples and controls were distributed to antigen-coted plate and any specific antibodies were bound to the antigen. Then plate was washed, and an anti-ruminant conjugate was added. The unbound conjugate was then washed out and chromogenic substrate was added. After stopping the reaction, the intensity of the resulting yellow colour, measured with a spectrophotometer, was proportional to the level of specific antibodies present in each well.

In the PrioCHECK ${ }^{\mathrm{TM}}$ Ruminant Q Fever Ab Plate Kit (Thermofisher, US) and PrioCHECK ${ }^{\mathrm{TM}} L$. Hardjo $\mathrm{Ab}$ Plate Kit (Thermofisher, US), the serum was dispensed to the inactivated-antigen coated plate and antibodies were bound during incubation. The antibodies were then detected using an anti-bovine monoclonal antibody conjugated to horseradish peroxidise enzyme. The bound conjugate was visualised by incubation with Chromogen (TMB) Substrate. After stopping the reaction, the intensity of colour was measured with a spectrophotometer.

For the PrioCHECK ${ }^{\mathrm{TM}}$ Bovine Neospora Ab 2.0 Serum/Milk Kit (Thermofisher, US), the samples were 
distributed and washed, and an anti-bovine conjugate labelled with peroxidase (HRP) was added and bound to the antibodies joined with the antigens on the plate. The plate was washed, and a chromogenic substrate and stopping solution were added. After stopping, the intensity of the resulting yellow colour, measured with a spectrophotometer, was proportional to level of the specific antibodies in the sample. A similar principle was used in the Vetline Toxoplasma ELISA KIT (Ingenasa, Spain).

\section{Statistical analysis}

The occurrence of antibodies to Chlamydia spp., N. caninum and T. gondii was analyzed statistically. A separate model was built for each pathogen, where the presence of antibodies for a given pathogen was analyzed as the dependent binary variable: the number 1 indicated present, and 0 absent. A similar set of independent variables was applied: age (years) and sex of animal, and location of the sample collection. The location of sample collection was assigned eight categories based on the sampled herd: the free-ranging herds from the Białowieska Forest, Borecka Forest, Knyszyńska Forest and Bieszczady were assigned four categories, the captive herds from Białowieża, Pszczyna and Niepołomice were assigned three, and the other captive herds with limited sample numbers were combined into one.

The data was analyzed using a generalized linear model with binomial distribution and logit link function [67]. The best fitting model was selected using a backward elimination procedure with an AIC value comparison. The statistical analyses were performed using SPSS.

As not all the blood samples were tested for each pathogen, the numbers of observations differed between models.

\section{Abbreviations}

BTB: Bovine tuberculosis; BIA: Białowieska Forest; BIE: Bieszczady Mountains; BIA $_{c}$ : Białowieża (captive); BOR: Borecka Forest; KNY: Knyszyńska Forest; OT-C: Other enclosures (captive); NI: Niepołomice (captive); PS.: Pszczyna (captive)

\section{Supplementary Information}

The online version contains supplementary material available at https://doi. org/10.1186/s12917-021-03057-8.

Additional file 1: Table S1. Significant differences in frequency of infection with Chlamydia spp. in European bison in free-ranging and captive conditions: Free-ranging: BIA - Białowieska Forest, BOR - Borecka Forest, KNY - Knyszyńska forest, BIE - Bieszczady; Captive: BIA - Białowieża, $\mathrm{Ni}_{c}$ - Niepołomice, PS $_{c}-$ Pszczyna, OT $_{c}$ - Other captive herds. Significant differences $(p<0.05)$ are presented for pairwise comparisons with Sidak correction.

Additional file 2: Table S2. Significant differences in frequency of infection with $N$. caninum in European bison in free-ranging and captive conditions: Free-ranging: BIA - Białowieska Forest, BOR - Borecka Forest, KNY - Knyszyńska forest, BIE - Bieszczady; Captive: BIA - Białowieża,
$\mathrm{Ni}_{c}$ - Niepołomice, $\mathrm{PS}_{c}-$ Pszczyna, OT $_{c}$ - Other captive herds. Significant differences are presented $(p<0.05)$ as pairwise comparisons with Least Significant Difference.

\section{Acknowledgements}

The authors would like to express their gratitude to Edward Lowczowski BSc for English correction of the text.

\section{Authors' contributions}

AD participated in designing and coordination of the study, laboratory work, material and data collection and drafting the manuscript. DK assisted in conceiving and designing the study, material and data collection, drafting the manuscript and statistical analysis. $\mathrm{AH}, \mathrm{BO}$ participated in laboratory analysis and drafting the manuscript. MG assisted in laboratory analysis, material and data collection. MR participated in drafting the manuscript. WO participated in designing and coordination of the study. KA participated in designing, coordination of the study and drafting the manuscript. All authors read and approved the final version of the manuscript.

\section{Funding}

The work was supported by the project "Complex project of European bison conservation by State Forests", which is financed by the Forest Found (Poland), contract no OR.271.3.10.2017. The role of the funder was to purchase serological tests and to cover the publication fee. The funder was not involved in the study design; collection, analysis and interpretation of the data; or in writing the manuscript.

\section{Availability of data and materials}

The datasets used and/or analysed during the current study are available from the corresponding author on reasonable request.

\section{Declarations}

\section{Ethics approval and consent to participate}

The lethal control was carried out by local institutions responsible for European bison management, and each culling was performed with the necessary permit. Collection and storing of serum samples from dead animals was based on the decision of the Regional Director of Environmental Protection in Warsaw. According to the decision, the collection of dead animals for scientific purposes does not need any permit as. Ante-mortem sampling was conducted as part of standard veterinary care and does not require approval according to II Local Ethical Committee For Animal Experiments in WULSSGGW in Warsaw.

\section{Consent for publication}

Not applicable.

\section{Competing interests}

The authors declare that they have no competing interests.

\section{Author details}

${ }^{1}$ Department of Food Hygiene and Public Health Protection, Institute of Veterinary Medicine, Warsaw University of Life Sciences (SGGW), Nowoursynowska 166, 02-787 Warsaw, Poland. ${ }^{2}$ Department of Animal Genetics and Conservation, Institute of Animal Sciences, University of Life Sciences (SGGW), Ciszewskiego 8, 02-786 Warsaw, Poland. ${ }^{3}$ Department of Preclinical Sciences, Institute of Veterinary Medicine, Warsaw University of Life Sciences (SGGW), Ciszewskiego 8, 02-786 Warsaw, Poland.

Received: 3 December 2020 Accepted: 25 October 2021

Published online: 04 November 2021

\author{
References \\ 1. Olech W, Klich D, Perzanowski K. Development of a new Action Plan for \\ the European bison. Oryx. 2019;53:214. \\ 2. Pucek Z. Postępy i zagrożenia restytucji żubra. Kosmos. 1994;43:47-169.
}


3. Raczyński J. Księga rodowodowa żubrów; 2020.

4. Klich D, Olech W, Cielniak K. A complex project for the conservation of European bison in Poland by State Forests. Eur Bison Conserv Newslett. 2017;10:11-20.

5. Klich D, Olech W, Łopucki R, Danik K. Community attitudes to the European bison Bison bonasus in areas where its reintroduction is planned and in areas with existing populations in northeastern Poland. Eur J Wildl Res. 2018. https://doi.org/10.1007/s10344-018-1219-5.

6. Olech $\mathrm{W}$. The changes of founders' number and their contribution to the European bison population during 80 years of species' restitution. Eur Bison Conserv Newslett. 2009;22:54-60.

7. Bielecki W, Amarowicz J, Hławiczka M, Kaczor S, Krzysiak M, Kuberka K, et al. Monitoring zdrowia populacji żubrów jako element ochrony gatunku. European Bison Conserv Newslett. 2014;7:43-50.

8. Klich D, Łopucki R, Stachniuk A, Sporek M, Fornal E, Wojciechowska M, et al. Pesticides and conservation of large ungulates: health risk to European bison from plant protection products as a result of crop depredation. PLoS One. 2020a;15(1):e0228243.

9. Klich D, Kitowski I, Łopucki R, Wiącek D, Olech W. Essential differences in the mineral status of free-ranging European bison Bison bonasus populations in Poland: The effect of the anthroposphere and lithosphere. Sci Total Environ. 2021;757:143926.

10. Krzysiak MK, Larska M, Jabłoński A, Bołbot M. Zakaźne i inwazyjne zagrożenia zdrowia i życia żubrów (Bison bonasus) w XX wieku. Życie Weterynaryjne. 2017;92:654-7.

11. Didkowska A, Orłowska B, Witkowski L, Olbrych K, Brzezińska S, Augustynowicz-Kopeć E, et al. Biopsy and tracheobronchial aspirates as additional tools for the diagnosis of bovine tuberculosis in living European bison (Bison bonasus). Animals (Basel). 2020. 33147754. https://doi. org/10.3390/ani10112017.

12. Angelakis E, Raoult D. Q Fever. Vet Microbiol. 2010;140:297-309.

13. Dubey JP, Schares G. Neosporosis in animals-the last five years. Vet Parasitol. 2011;180:90-108.

14. Reinhold P, Sachse K, Kaltenboeck B. Chlamydiaceae in cattle: commensals, trigger organisms, or pathogens? Vet J. 2011;189:257-67.

15. Krzysiak MK, Jabłoński A, Iwaniak W, Krajewska M, Kęsik-Maliszewska J, Larska M. Seroprevalence and risk factors for selected respiratory and reproductive tract pathogen exposure in European bison (Bison bonasus) in Poland. Vet Microbiol. 2018;215:57-65

16. Kita J, Anusz K. Serologic survey for bovine pathogens in free-ranging European bison from Poland. J Wildl Dis. 1991;27:16-20.

17. Rzewuska M, Stefańska I, Osińska B, Kizerwetter-Świda M, Chrobak D, Kaba J. Phenotypic characteristics and virulence genotypes of Trueperella (Arcanobacterium) pyogenes strains isolated from European bison (Bison bonasus). Vet Microbiol. 2012. https://doi.org/10.1016/j.vetmic.2012.05. 004.

18. Quinn PJ, Markey BK, Leonard FC, FitzPatrick ES, Fanning S, Hartigan P. Chlamydia and Chlamydophila in Veterinary Microbiology and Microbial Disease. 2nd ed; 2011. p. 384-93.

19. Sachse K, Laroucau K. Two more species of Chlamydia-does it make a difference? Pathog Dis. 2015. https://doi.org/10.1093/femspd/ftu008.

20. Piercy DW, Griffiths PC, Teale CJ. Encephalitis related to Chlamydia psittaci infection in a 14-week-old calf. Vet Rec. 1999;144:126-8.

21. Wittenbrink MM, Schoon HA, Bisping W, Binder A. Infection of the bovine female genital tract with Chlamydia psittaci as a possible cause of infertility. Reprod Domest Anim. 1993;28:129-36.

22. Szymańska-Czerwińska M, Niemczuk K, Galińska ME. Serological and nested PCR survey to determine the occurrence of chlamydia infections in the Polish cattle population. Ann Agric Environ Med. 2013;20:682-6.

23. Bharti A, Nally JE, Ricaldi JN, Matthias MA, Diaz MM, Lovett MA. Leptospirosis: A zoonotic disease of global importance. Lancet Infect Dis. 2003;3:757-71.

24. Levett PN. Leptospirosis. Clin Microbiol Rev. 2001;14:296-326.

25. Wasiński B, Sroka J, Wójcik-Fatla A, Zając V, Cisak E, Knap JP, et al. Occurrence of leptospirosis in domestic animals reared on exposed or non-exposed to flood areas of eastern Poland. Bull Vet Inst Pulawy. 2012. https://doi.org/10.2478/v10213-012-0086-1.

26. Adler B, de la Peña MA. Leptospira and Leptospirosis. Vet Microbiol. 2010;27:287-96.
27. Angelakis E, Raoult D. Pathogenicity and treatment of Bartonella infections. Int J Antimicrob Agents. 2014. https://doi.org/10.1016/j.ijantimicag. 2014.04.006.

28. Pexara A, Solomakos N, Govaris A. Q fever and seroprevalence of Coxiella burnetii in domestic ruminants. Vet Ital. 2018;54:265-79.

29. Kmieciak W, Ciszewski M, Szewczyk E. Choroby odkleszczowe w Polsce występowanie i trudności w diagnostyce. Med Pr. 2016;67:73-87.

30. Nowak-Chmura M, Siuda K. Ticks of Poland. Review of contemporary issues and latest research. Ann Parasitol. 2012;58:125-55.

31. Karbowiak G, Demiaszkiewicz AW, Pyziel AM, Wita I, Moskwa B, Werszko J, et al. The parasitic fauna of the European bison (Bison bonasus) (Linnaeus, 1758) and their impact on the conservation. Part 1. The summarising list of parasites noted. Acta Parasitol. 2014;59:363-71.

32. González-Barrio D, Ruiz-Fons F. Coxiella burnetii in wild mammals: A systematic review. Transbound Emerg Dis. 2019;66:662-71.

33. Lefkaditis M, Mpairamoglou R, Sossidou A, Spanoudis K, Tsakiroglou M. Neospora caninum, A potential cause of reproductive failure in dairy cows from Northern Greece. Vet Parasitol Reg Stud Reports. 2020;19:100365.

34. Almería S. Neospora caninum and Wildlife. ISRN Parasitol. 2013. https://doi. org/10.5402/2013/947347.

35. Stelzer S, Basso W, Benavides Silván J, Ortega-Mora LM, Maksimov P, Gethmann J, et al. Toxoplasma gondii infection and toxoplasmosis in farm animals: Risk factors and economic impact. Food Waterborne Parasitol. 2019;15:e00037.

36. Fereig RM, Mahmoud HYAH, Mohamed SGA, AbouLaila MR, Abdel-Wahab A, Osman SA, et al. Seroprevalence and epidemiology of Toxoplasma gondii in farm animals in different regions of Egypt. Vet Parasitol Reg Stud Rep. 2016;3-4:1-6.

37. Dahourou LD, Gbati OB, Savadogo M, Yougbare B, Dicko A, Combari AHB, et al. Prevalence of Toxoplasma gondii and Neospora caninum infections in households sheep "Elevage en case" in Dakar, Senegal. Vet World. 2019;12(7):1028-32.

38. Semango G, Hamilton CM, Kreppel K, Katzer F, Kibona T, Lankester F, et al. The Sero-epidemiology of Neospora caninum in Cattle in Northern Tanzania. Front Vet Sci. 2019;6:327.

39. Sun LX, Liang QL, Nie LB, Hu XH, Li Z, Yang JF, et al. Serological evidence of Toxoplasma gondii and Neospora caninum infection in black-boned sheep and goats in southwest China. Parasitol Int. 2020;75:102041. https://doi.org/10.1016/j.parint.2019.102041.

40. Abdallah MC, Kamel M, Karima B, Samir A, Djamel K, Rachid K, et al. CrossSectional survey on Toxoplasma gondii infection in cattle, sheep, and goats in Algeria: seroprevalence and risk factors. Vet Sci. 2019;6(3):63.

41. Hireche S, Bouaziz O, Djenna D, Boussena S, Aimeur R, Kabouia R, et al. Seroprevalence and risk factors associated with Chlamydophila spp. infection in ewes in the northeast of Algeria. Trop Anim Health. 2014;46(2):467-73.

42. Salinas J, Caro MR, Vicente J, Cuello F, Reyes-Garcia AR, Buendía AJ, et al. High prevalence of antibodies against Chlamydiaceae and Chlamydophila abortus in wild ungulates using two "in house" blocking-ELISA tests. Vet Microbiol. 2009:135(1-2):46-53.

43. Salwa A, Anusz K, Arent Z, Paprocka G, Kita J. Seroprevalence of selected viral and bacterial pathogens in free-ranging European bison from the Białowieza Primeval Forest (Poland). Pol J Vet Sci. 2007;10:19-23.

44. Carta T, Álvarez J, de la Lastra JP, Gortázar C. Wildlife and paratuberculosis: a review. Res Vet Sci. 2013. https://doi.org/10.1016/j.rvsc.2012.11.002.

45. Cubero-Pablo MJ, Plaza M, Pérez L, González M, León-Vizcaíno L. Seroepidemiology of chlamydial infections of wild ruminants in Spain. J Wildl Dis. 2000;36(1):35-47. https://doi.org/10.7589/0090-3558-36.1.35.

46. Ciecierski H, Anusz K, Borko K, Anusz Z, Tsakalidis S. Occurrence of antibodies against Coxiella burnetii in wild animals in the foci of $Q$ fever in 1985-1988. Med Wet. 1988:44:652-4.

47. Krzysiak MK, Puchalska M, Olech W, Anusz K. A Freedom of Coxiella burnetii Infection Survey in European Bison (Bison bonasus) in Poland. Animals (Basel). 2021;11(3):651.

48. Fernández-Aguilar X, Cabezón Ó, Colom-Cadena A, Lavín S, López-Olvera $J R$. Serological survey of Coxiella burnetii at the wildlife-livestock interface in the Eastern Pyrenees, Spain. Acta Vet Scand. 2016. https://doi.org/10. 1186/s13028-016-0209-4.

49. Tavernier P, Sys SU, De Clercq K, De Leeuw I, Caij AB, De Baere M, et al. Serologic screening for 13 infectious agents in roe deer (Capreolus 
capreo/us) in Flanders. Infect Ecol Epidemiol. 2015. https://doi.org/10. 3402/iee.v5.29862.

50. Cabaj W, Moskwa B, Pastusiak K, Gill J. Antibodies to Neospora caninum in the blood of European bison (Bison bonasus bonasus L.) living in Poland. Vet Parasitol. 2005;128:163-8.

51. Bień J, Moskwa B, Cabaj W. In vitro isolation and identification of the first Neospora caninum isolate from European bison (Bison bonasus bonasus L.). Vet Parasitol. 2010;173:200-5.

52. Davison HC, Otter A, Trees AJ. Estimation of vertical and horizontal transmission parameters of Neospora caninum infections in dairy cattle. Int J Parasitol. 1999;29:1683-9.

53. McAllister MM, Dubey JP, Lindsay DS, Jolley WR, Wills RA, McGuire AM. Dogs are definitive hosts of Neospora caninum. Int J Parasitol. 1998;28:1473-8.

54. Gondim LFP, MCAllister MM, Pitt WC, Zemlicka DE. Coyotes (Canis latrans) are definitive hosts of Neospora caninum. Int J Prasitol. 2004;34:159-61.

55. King JS, Slapeta J, Jenkins DJ, Al-Qassab SE, Ellis JT, Windsor PA. Australian dingoes are definitive hosts of Neospora caninum. Int J Parasitol. 2010;40:945-50

56. Kaczor S, Januszczak M, Wołoszyn-Gałęza A, Jankowski W. The first documented case of wolf predation on the wisent in the Lesko Forest District: International Conference "Żubry w Białowieskim Mateczniku", Białowieża, Conference Materials; 2019. p. 53-4.

57. Orłowska B, Augustynowicz-Kopeć E, Krajewska M, Zabost A, Welz M, Kaczor $\mathrm{S}$, et al. Mycobacterium caprae transmission to free-living grey wolves (Canis lupus) in the Bieszczady mountains in southern Poland. Eur J Wild Res. 2017:63:1-5.

58. Goździk K, Nowak S, Bień J, Mysłajek R. Examination of pathogens affecting wolves in Southern Poland - a preliminary results. Ann Parasitol. 2016;62(Supp):20
59. Gielarek S, Klich D, Antosiewicz M. Forest cover change in Western Bieszczady Mts. in 19 th and 20 th century. Sylwan. 2011;155(12):835-42.

60. Kania-Gierdziewicz J, Mroszczyk B. Use and breeding of livestock guarding dogs in the Subcarpathian area. Wiad Zootech. 2017;2:129-38.

61. Sroka J, Karamon J, Wójcik-Fatla A, Piotrowska W, Dutkiewicz J, BilskaZając E, et al. Toxoplasma gondii infection in slaughtered pigs and cattle in Poland: seroprevalence, molecular detection and characterization of parasites in meat. Parasite Vector. 2020. https://doi.org/10.1186/ s13071-020-04106-1.

62. Majewska AC, Werner A, Cabaj W, Moskwa B. The first report of Toxoplasma gondii antibodies in free-living European bison (Bison bonasus bonasus Linnaeus). Folia Parasitol. 2014;61:18-20.

63. Shapiro K, Bahia-Oliveira L, Dixon B, Dumètre A, de Wit LA, VanWormer E, et al. Environmental transmission of Toxoplasma gondii: Oocysts in water, soil and food. Food Waterborne Parasitol. 2019;15:e00049.

64. Moskwa B, Bień J, Kornacka A, Cybulska A, Goździk K, Krzysiak MK, et al. First Toxoplasma gondii isolate from an aborted foetus of European bison (Bison bonasus bonasus L.). Parasitol Res. 2017;16:2457-61.

65. Witkowski L, Czopowicz M, Nagy DA, Potarniche AV, Aoanei MA, Imomov $\mathrm{N}$, et al. Seroprevalence of Toxoplasma gondii in wild boars, red deer and roe deer in Poland. Parasite (Paris, France). 2015;22:17.

66. Krzysiak M, Larska M. Immobilizacja farmakologiczna żubrów. Med Wet. 2014;70(3):172-5.

67. Hardin JW, Hardin JW, Hilbe JM, Hilbe J. Generalized linear models and extensions: Stata press; 2007.

\section{Publisher's Note}

Springer Nature remains neutral with regard to jurisdictional claims in published maps and institutional affiliations.
Ready to submit your research? Choose BMC and benefit from:

- fast, convenient online submission

- thorough peer review by experienced researchers in your field

- rapid publication on acceptance

- support for research data, including large and complex data types

- gold Open Access which fosters wider collaboration and increased citations

- maximum visibility for your research: over $100 \mathrm{M}$ website views per year

At BMC, research is always in progress.

Learn more biomedcentral.com/submissions 